\title{
The Peculiarities of the Correction of Psychomotor Disorders of Patients with Ischemic Stroke: the Psychological Aspect
}

\section{Особливості корекції психомоторних розладів хворих на ішемічний інсульт: психологічний аспект}

\section{Yevhen Kharchenko} (Ukraine)

Dr. in Medicine, Professor, Rivne Medical Academy, Rivne

ORCID ID: https://orcid.org/0000-0002-4340-8503

Researcher ID: http://www.researcherid.com/rid/AAU-7523-2020

E-mail: kharchenko.yevh@gmail.com

\section{Свген Харченко}

Доктор медичних наук, професор, Рівненська медична академія, м. Рівне (Україна)

\section{Iryna Vashchenko}

Dr. in Psychology, Professor, Taras Shevchenko National University of Kyiv, Kyiv (Ukraine)

ORCID ID: https://orcid.org/0000-0003-4424-5790

Researcher ID: http://www.researcherid.com/rid/C-4934-2019

E-mail: jarinavv62@gmail.com

\section{Ірина Ващенко}

Доктор психологічних наук, професор, Київський національний університет імені Тараса Шевченка, м. Київ (Україна)

The contribution of the author: Kharchenko Ye. - 50\%, Vashchenko I. - 50\%. Авторський внесок: Харченко Є.- 50\%, Ващенко І. - 50\%.

Address for correspondence, e-mail: kpnu_lab_ps@ukr.net Copyright: (C) Kharchenko Yevhen, Vashchenko Iryna

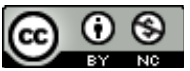
The article is licensed under CC BY-NC 4.0 International (https://creativecommons.org/licenses/by-nc/4.0/)

(C) Kharchenko Yevhen, Vashchenko Iryna

DOI (article): https://doi.org/10.32626/2227-6246.2021-53.284-305 


\section{ABSTRACT}

The objectives of article are: to propose the author's view on biomechanical laws which show the picture of disorders of psychomotor function; to make the research and to analyze obtained data on the initial state of motor function of patients with ischemic stroke of the subgroup "plesia + paresis»; to propose psychological principles of the development of general compensatory reactions of the patient in a case of physical rehabilitation of patients with ischemic stroke.

Methods of the research. We used the method of the analysis of literature sources; the method of pedagogical observation; psychological and pedagogical experiment; providing the research of psycho-emotional state ( $M$. Lucher's test is used).

The results of the research. We proved that regardless of the level of disorders, the picture of disorders of psychomotor function is subjected to certain biomechanical laws: 1 . The rule of redistribution of functions of the affected limb. The functionality of the affected limb to maintain body weight is significantly reduced. This is especially noticeable in the period of single support: decreases both absolute and relative in time intervals of the function of single support, as well as the duration of the period of this support. But this kind of unloading of the sick side must be compensated, because the period of support of a healthy leg increases significantly. The change of periods of support has an obvious consequence - the increase of the sick side of the transfer time, also of the healthy side - we mean its reduction. 2. The rule of functional copying of another person's movements. Pathological asymmetry is not beneficial to the body in terms of energy or mechanics. The need to maintain the relative symmetry of the function of the right and left sides of the body leads to the following conclusion: the healthy side of the body (or a limb) has a considerable functional reserve than a sick limb, so the reduction of functional asymmetry occurs by approximating the pattern of functioning of a healthy limb. 3. The rule of ensuring the optimum in psychomotor activity. The functioning of all elements of the normal cycle of psychomotor activity is the basis of physiological optimality of the individual. Any deviations from physiological optimality require the inclusion of additional adaptive reserves, which are slightly altered on the affected side. It is possible to provide the patient with optimal functioning due to the functional stress of a healthy side.

Conclusions. We proposed psychological principles of the development of general compensatory reactions of the patient in a case of physical rehabilitation of patients with ischemic stroke were proposed in this research. These

(c) Kharchenko Yevhen, Vashchenko Iryna DOI (article): https://doi.org/10.32626/2227-6246.2021-53.284-305 
DOI: https://doi.org/10.32626/2227-6246.2021-53

2021. виПуСК 53

principles are: 1) the principle of actualization of the defect; 2) the principle of progressive mobilization of compensatory mechanisms of psychomotor activity; 3) the principle of continuous reverse of concentration of compensatory mechanisms of the psyche of the person; 4) the principle of sanctioning compensatory mechanisms of the psyche of the person; 5) the principle of relative stability of the compensatory mechanisms of the psyche of the patient.

It was proved that in a case of ischemic strokes there is a certain dynamics of recovery of locus disorders. Firstly, reflex functions and tone are restored, then psychomotor actions (global and coordinating synkinesis) and auxiliary actions appear, and finally arbitrary movements are restored. In order to begin to restore tendon reflexes and muscle tone, it is necessary to normalize the functions of the spinal cord.

We emphasized that compensation of certain function that had disorders is based on the restructuring of the old stereotype and the development of a new dynamic stereotype. The most important point of compensation for structural and functional disorders in the case of psychomotor pathology is active participation in the rehabilitation process and the patient himself/herself, who should seek to activate the body's systems, which are not affected at all or suffered insignificantly. It has been shown that due to new unaffected parts of the central nervous system, it is possible to rearrange the innervation between the antagonists.

Key words: psychomotor disorders of patients, ischemic stroke, the principle of actualization of the defect, the principle of progressive mobilization of compensatory mechanisms of psychomotor activity, the principle of continuous reverse of concentration of compensatory mechanisms of the psyche of the person.

\section{Introduction}

Motor disorders can be distinguished (by the type of their genesis) on primary-organic and psychogenic motor disorders. In the case of primary-organic motor disorders pathological changes are observed in the muscular, skeletal or nervous systems, however, in the conditions of psychogenic motor disorders the presence of such changes proved to be objectively impossible. To describe motor disorders of a patient, first of all, it is necessary to know: a) what functions must be distin(c) Kharchenko Yevhen, Vashchenko Iryna

DOI (article): https://doi.org/10.32626/2227-6246.2021-53.284-305 http://journals.uran.ua/index.php/2227-6246 
guished in the cases of the process of motor regulation of a person; b) in what forms the disorders of these functions are revealed. The main differences observed between disorders are: a) initiation of actions; b) frustration in their presentation. In the cases of doing the actions there are disorders of the programmed control, regulation and coordination (Харченко \& Куриця, 2021).

The main characteristic of the regulation of movements is the integration of regulation of motor processes, through which movements are more or less continuously adapted to the world and other autonomous processes, which are often referred to as regulation by a human psychomotor program. The essence of disorders of regulatory processes is manifested primarily in motor disorders that occur when the distortion of feedback takes a place. The essence of autonomous processes that are independent of sensory feedback coming from the periphery of the body, is manifested in the fact that because of the absence of feedback (including feedback from the senses, feedback in the muscles and joints) the ability to move is still preserved (Khwaja, 2012).

The regulation of movements is also when the movement is initially as if it is listed in the distal relation. Performing a certain action, the muscles should be involved in such a way that the desired result is achieved, in this case we mean the desired psychomotor skills. The relationships between the motor command given to an individual by muscles and the actions we call «movement» as a result of so-called «transformation of the body»; for successful traffic control this transformation must be inverted. Disorders in the case of human mastery of the body transformation are usually processes of disorders' coordination: different muscles do not «agree» with each other in the appropriate temporal and/or forceful relationships (Hayden, Farrar \& Peiris, 2014).

Arbitrary movements are usually preceded by a corresponding intention or a plan. From a functional point of view

(c) Kharchenko Yevhen, Vashchenko Iryna DOI (article): https://doi.org/10.32626/2227-6246.2021-53.284-305 
DOI: https://doi.org/10.32626/2227-6246.2021-53

2021. випуск 53

the intention can be characterized as «a rule of initiation" (Hardeman, Medina \& Kozhimannil, 2016), which connects the call of the psychomotor program with the criteria of this action (the criteria of the action can be: the team of a doctor, the instructor, etc.).

The establishment of rules for initiating actions is not always accompanied by the intention to make a certain move by a person. The rules of initiation of people are quite flexible, but still any psychomotor program can occur with different speed and with varying degrees of reliability. A very fast and reliable call is made when the criteria of some action correspond to the spatial or other features, which are subordinate to the first movement of the person (Онуфрієва \& Івашкевич, 2021).

Programming the management of psychomotor activity assumes that this activity is caused by mnemonic processes. In the case of disorders in the measures of psychomotor program it can be expected that the patient will be able to perform a certain movement spontaneously, but not at the request of the doctor. Such patients provide the representation of those positions that have to be taken by a certain part of the body, and they directly perform psychomotor activity (Mykhalchuk, Pelekh, Kharchenko, Ivashkevych Ed., Ivashkevych Er., Prymachok, Hupavtseva \& Zukow, 2020).

In the scientific literature some scientists (Villar, Blanco \& del Campo, 2015) distinguish disorders of programming the management of psychomotor activity between the programs for managing psychomotor activities and emphasize on plans for providing these psychomotor activities. According to this terminology, psychomotor management programs are a stereotypical sequence of commands in the central nervous system that determine the order of innervation of various muscles. The main plans of psychomotor activity coordinate several motor programs and adapt them to contemporary environmental conditions. The program of psychomotor activity provides a clear sequence in the facilitation of agonists and antagonists. (c) Kharchenko Yevhen, Vashchenko Iryna

DOI (article): https://doi.org/10.32626/2227-6246.2021-53.284-305 
DOI: https://doi.org/10.32626/2227-6246.2021-53

2021. ВИПУСК 53

This sequence of muscle activations leads to a smooth, well-directed movement, characterized by the maximum performance of rapid reactions. By varying the time intervals between the activation of agonists and antagonists and modulating the strength of individual muscle activations. It is possible to achieve (within the same motor program of psychomotor activity) different speed and amplitude of this activity.

In the most cases the performance of psychomotor activities, which is adequate to the world around, is due to human vision. This visual-motor coordination of movements seems quite clear and trivial. However, its development depends on the presence of certain conditions and may be somewhat disturbed. The apparent naturalness of some functions, such as visual-motor coordination, obviously does not mean that the system that implements these functions is quite simple and healthy, but only in such a case its activity is not accompanied by a conscious experience of psychomotor activity (Onufriieva, Chaikovska, Kobets, Pavelkiv \& Melnychuk, 2020).

Disorders of coordination of psychomotor activity in the implementation of a certain purposeful psychomotor activity often involve muscles, which must contract in a certain sequence and with a certain intensity. At the same time we can talk about some tolerance for mistakes, because often the same result of movements can be achieved through different patterns of reduction, but, of course, there are boundaries beyond which psychomotor activity fails. The desired result of psychomotor activity depends on a certain form of its implementation. The coordination of the contracting muscles is ultimately carried out without any involvement of our consciousness. Therefore, we can argue that such a system with many components, which should be expected to work quite accurately together, is easily susceptible for disorders. One of the simplest forms of psychomotor coordination disorder can be a kind of «excessive activity», when instead of a well-coordinated joint

(C) Kharchenko Yevhen, Vashchenko Iryna DOI (article): https://doi.org/10.32626/2227-6246.2021-53.284-305 
DOI: https://doi.org/10.32626/2227-6246.2021-53

2021. випуск 53

activity of different muscles muscle tension as a whole increases, and at this high level this tension can be modulated with a great difficulties, performing psychomotor activities.

Thus, as a result of a clearly coordinated interaction of the above functional systems there is a completely individual level of arbitrary motility, which is inherent for each individual. Thus, disorders in complex motor systems result from cerebral ischemic stroke can not be manifested in stereotyped psychomotor deficits, and it is almost always presented by a complex and completely ambiguous clinical picture.

The objectives of our article are: to propose the author's view on biomechanical laws which show the picture of disorders of psychomotor function; to make the research and to analyze obtained data on the initial state of motor function of patients with ischemic stroke of the subgroup «plesia + paresis»; to propose psychological principles of the development of general compensatory reactions of the patient in a case of physical rehabilitation of patients with ischemic stroke.

\section{Methods of the research}

The following research methods were used to solve the tasks having been set in our research:

Psychological and pedagogical research methods:

1. The analysis of literature sources.

2. The method of pedagogical observation.

3. Psychological and pedagogical experiment.

4. Providing the research of psycho-emotional state (M. Lucher's test is used).

The empirical research was provided at the Department of Human Health and Physical Therapy of the International University of Economics and Humanities named after Academician Stepan Demianchuk on the basis of Ternopil Regional Municipal Clinical Psychoneurological Hospital, Neurological Department for Patients with Cerebral Circulatory Disorders (Neuroreability Unit).

C Kharchenko Yevhen, Vashchenko Iryna

DOI (article): https://doi.org/10.32626/2227-6246.2021-53.284-305 
In accordance with the purpose of the research and in order to solve the tasks, in our experiment 50 patients with ischemic stroke were participated who had disturbances in the area of the internal carotid artery in the acute and residual period, who were treated at the Ternopil Regional Communal Clinical Psycho-neurological Hospital during the period from January to December, 2020.

The diagnosis of ischemic stroke was made in the neurological department for patients with cerebral circulatory disorders on the basis of the characteristic of clinical picture, data of the laboratory and instrumental research methods according to the "International Statistical Classification of Diseases and Related Health Problems».

\section{Results and their discussion}

In this case, regardless of the level of disorders, the picture of disorders of psychomotor function is subjected to certain biomechanical laws [55]:

1. The rule of redistribution of functions of the affected limb.

The functionality of the affected limb to maintain body weight is significantly reduced. This is especially noticeable in the period of single support: decreases both absolute and relative in time intervals of the function of single support, as well as the duration of the period of this support. But this kind of unloading of the sick side must be compensated, because the period of support of a healthy leg increases significantly. The change of periods of support has an obvious consequence the increase of the sick side of the transfer time, also of the healthy side - we mean its reduction.

The rule of redistribution of functions is understood in such a way that a healthy limb performs mainly the functions of support, and the patient - mainly the function of transfer.

2. The rule of functional copying of another person's movements. Pathological asymmetry is not beneficial to the

(C) Kharchenko Yevhen, Vashchenko Iryna DOI (article): https://doi.org/10.32626/2227-6246.2021-53.284-305 
DOI: https://doi.org/10.32626/2227-6246.2021-53

2021. випуск 53

body in terms of energy or mechanics. The need to maintain the relative symmetry of the function of the right and left sides of the body leads to the following conclusion: the healthy side of the body (or a limb) has a considerable functional reserve than a sick limb, so the reduction of functional asymmetry occurs by approximating the pattern of functioning of a healthy limb.

The rule of functional copying of movements of another person also consists that the healthy extremity copies function of the patient for the purpose of leveling of functional asymmetry.

\section{The rule of ensuring the optimum in psychomotor ac- tivity.}

The functioning of all elements of the normal cycle of psychomotor activity is the basis of physiological optimality of the individual. Any deviations from physiological optimality require the inclusion of additional adaptive reserves, which are slightly altered on the affected side. It is possible to provide the patient with optimal functioning due to the functional stress of a healthy side.

The rule of ensuring the optimum is in such a case, first of all, that the diseased limb is provided with a mode of functioning that is significantly close to normal due to the functional stress of a healthy limb.

The study of the structure and patterns of pathological walking shows that in the presence of pathology a person adheres to the same principle of organization of the muscles of antagonists, which at this time function normally. According to this principle, the extensor muscles perform mainly a power function, while the activity of the extensor muscles acquires predominantly a corrective character. And this relationship in the case of any other pathology is also not violated.

The joint participation of extensor muscles and flexor muscles in compensatory conditions in pathological walking in the conditions of movements of the center of gravity does not indicate a loss of differences between their innervation (C) Kharchenko Yevhen, Vashchenko Iryna

DOI (article): https://doi.org/10.32626/2227-6246.2021-53.284-305 
programs. On the contrary, in the conditions of considerable roughening of the locomotor act these differences appear more significant: roughening of muscles during a psychomotor cycle, simultaneous excitation of extensor muscles, great variability of phases of the activity of flexor muscles affects.

Muscles during the locomotor cycle of normal walking sometimes work in the step-by-step, then in the visual mode. The duration of the regimes is determined by the boundaries of the biomechanical phases. The translational regime normally dominates the extensor muscles, while the flexor muscles are roughly the same ones. In general, walking of patients with hemiparesis is characterized by: slowing down the pace of psychomotor activity; short stride length; low speed of psychomotor activity; by changing the locomotor cycle of normal walking.

Here are the clinical characteristics of the respondents. The study included 50 patients with ischemic stroke in the area of the internal carotid artery. There are 22 people $(44 \%)$ with lesions of the left middle cerebral artery, 28 people (56\%) have middle cerebral artery.

The characteristics of patients by age are presented in Table 1. Thus, the average age of patients was 55 years. As we can see from Table 1, the majority of people $-42(84 \%)$ - are suffering from ischemic stroke and they were over the age of 45 , which indicates a rejuvenation of stroke in Ukraine.

Table 1

The characteristics of patients by their age

\begin{tabular}{|l|c|c|c|c|}
\hline \multicolumn{1}{|c|}{ Age of patients } & $\begin{array}{c}\text { Up to 45 } \\
\text { years old }\end{array}$ & $\begin{array}{c}\text { From 45 to } \\
\text { 65 years old }\end{array}$ & $\begin{array}{c}\text { Elder than } \\
\text { 65 years old }\end{array}$ & $\begin{array}{c}\text { Total- } \\
\text { ly }\end{array}$ \\
\hline Number of patients & 8 & 21 & 21 & 50 \\
\hline Percentage of patients & 16 & 42 & 42 & 100 \\
\hline
\end{tabular}

The etiological factor of the development of ischemic stroke of patients was various pathologies of the cardiovascular sys-

(c) Kharchenko Yevhen, Vashchenko Iryna DOI (article): https://doi.org/10.32626/2227-6246.2021-53.284-305 
DOI: https://doi.org/10.32626/2227-6246.2021-53

2021. випуск 53

tem: atherosclerotic lesions of cerebral vessels, hypertension, coronary heart disease, cardiac arrhythmias, thromboembolism. 22 patients $(44 \%)$ had a history of acute cerebrovascular accident.

All the patients were taken to the hospital within 6 hours from the onset of the disease for up to three days. In all cases, at the time of the examination, the conditions of the patients were considered moderate. The clinical picture was dominated by focal neurological symptoms over the general cerebral, there was no pronounced concomitant somatic pathology.

Due to the fact that all the patients having been examined had polymorphic disorders of voluntary movements due to damage to the motor systems as a result of ischemic stroke. In such a way the research of post-stroke motor deficit was detailed.

Violation of voluntary motility of patients with ischemic stroke have caused significant disorders of static and dynamic motor function of the arm and the leg on the affected side, coordinated movement of arms and legs, a head, torso, violation of the possibility of symmetrical holding of different positions (from the side to vertical position), ocular-motor disorders.

All the patients in the acute period of stroke underwent complex therapy with the aim of providing correcting disorders of central and cerebral hemodynamics, homeostasis, the fight against cerebral edema, metabolic therapy and so on.

In the research of the nature of complaints presented by patients at the beginning of their exercises, the following information was noted: complaints of headache, dizziness, hiccups, lack of any movement in the affected extremities (leg, arm, both extremities); on the pains arising at the movements in shoulder joints, in hip joints, the general weakness, disturbance of speech, disturbance of sensitivity, decrease in sight, disturbance of swallowing, bad sleep, irritability.

The following results were obtained by examining the volume of active, passive movements, strength and muscle tone (C) Kharchenko Yevhen, Vashchenko Iryna

DOI (article): https://doi.org/10.32626/2227-6246.2021-53.284-305 
of the affected extremities. Thus, for patients with hemiplegia $(n=12)$ in $82.3 \%$ of cases the volume of passive movements of the affected side was $33.11 \% \pm 3.6$ of the appropriate volume. Passive movements were limited by the onset of joint pain, probably due to sprains and age-related changes of the person.

The volume of active movements of the unaffected side averaged $43.98 \% \pm 5.7$ of the proper volume of movements. The rate of passive movements in the joints of the unaffected side was slightly lower than the rate of the affected side and amounted to $56.19 \% \pm 2.4$ of the proper amount of movement. The strength of the muscles of the unaffected side was estimated at an average of $3.45 \pm 0.40$ points, which was $51.6 \% \pm 2.9$ of normal and statistically significant (at the level of reliability $\mathrm{p}<\mathbf{0 . 0 1}$ according to Student's t-test) differed from the indicators of the affected party. The muscle tone of the unaffected side was higher than a normal one and was about $34.8 \% \pm 0.3$ of the maximum value $(p<0.05)$.

Data on the initial state of motor function of patients with ischemic stroke of the subgroup «plesia + paresis» are presented in Table 2.

As we can see from Table 2, for patients of the subgroup "plesia + paresis» in the case of studying the volume of active movements of the affected extremities we'll draw our attention to a significant decrease in the volume of movements in all joints. To the greatest extent the volume of movements is reduced under conditions of high tone in the hip joint when performing extension of actions; in the case of flexion in the knee joint, in flexion in the ankle joint. When a team performs an extension in the hip joint the patient often performs an extension in the lumbar spine, that performs a movement that replaces the given one.

In the research of passive movements of the affected extremities patients have a decrease, especially in the shoulder, hip and ankle joints, which, according to the data of the patient's history of the illness, suggests age-related changes in

(C) Kharchenko Yevhen, Vashchenko Iryna DOI (article): https://doi.org/10.32626/2227-6246.2021-53.284-305 
DOI: https://doi.org/10.32626/2227-6246.2021-53

2021. випуск 53

the joints or changes in motor functions due to hypokinesia before the disease.

Table 2

The research data on the volume of active and passive movements, strength and of muscle tone of the affected extremities of patients of the subgroup "plesia + paresis» $(n=18)$ at the beginning of the research $(M \pm T)$

\begin{tabular}{|c|c|c|c|c|}
\hline $\begin{array}{c}\text { Motor acts being } \\
\text { tested }\end{array}$ & 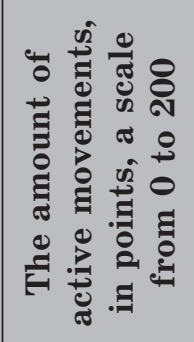 & 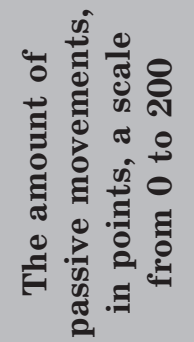 & 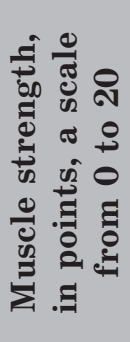 & 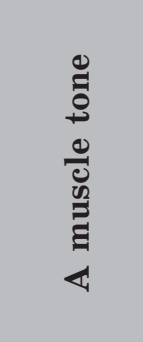 \\
\hline $\begin{array}{l}\text { Flexion and extension } \\
\text { in the shoulder joint } \\
\text { (the main group) }\end{array}$ & $11.7 \pm 4.5$ & $39.1 \pm 4.2$ & 5 & Reduced \\
\hline $\begin{array}{l}\text { Flexion and extension } \\
\text { in the shoulder joint } \\
\text { (the control group) }\end{array}$ & $19.0 \pm 1.8$ & $38.3 \pm 5.8$ & 5 & Reduced \\
\hline $\begin{array}{l}\text { Withdrawal of the arm } \\
\text { at the shoulder joint } \\
\text { (the main group) }\end{array}$ & $24.6 \pm 6.9$ & $31.9 \pm 1.0$ & 5 & Reduced \\
\hline $\begin{array}{l}\text { Withdrawal of the arm } \\
\text { at the shoulder joint } \\
\text { (the control group) }\end{array}$ & $21.7 \pm 4.2$ & $39.8 \pm 1.6$ & 5 & Reduced \\
\hline $\begin{array}{l}\text { The external and } \\
\text { internal rotation } \\
\text { in the shoulder joint } \\
\text { (the main group) }\end{array}$ & $17.0 \pm 3.7$ & $18.3 \pm 1.8$ & 4 & Reduced \\
\hline $\begin{array}{l}\text { The external and } \\
\text { internal rotation } \\
\text { in the shoulder joint } \\
\text { (the control group) }\end{array}$ & $18.3 \pm 1.5$ & $1.8 \pm 0.2$ & 4 & Reduced \\
\hline
\end{tabular}

(C) Kharchenko Yevhen, Vashchenko Iryna

DOI (article): https://doi.org/10.32626/2227-6246.2021-53.284-305 
DOI: https://doi.org/10.32626/2227-6246.2021-53

2021. ВИПУСК 53

\begin{tabular}{|c|c|c|c|c|}
\hline $\begin{array}{c}\text { Motor acts being } \\
\text { tested }\end{array}$ & $\begin{array}{c}\text { The } \\
\text { amount of } \\
\text { active ... }\end{array}$ & $\begin{array}{c}\text { The } \\
\text { amount of } \\
\text { passive ... }\end{array}$ & $\begin{array}{c}\text { Muscle } \\
\text { strength } \\
\ldots\end{array}$ & $\underset{\substack{\text { A } \\
\text { muscle } \\
\text { tone }}}{c}$ \\
\hline $\begin{array}{l}\text { Bending the arm } \\
\text { in elbow joints } \\
\text { (the main group) }\end{array}$ & $10.6 \pm 4.3$ & $19.1 \pm 6.7$ & 5 & Reduced \\
\hline $\begin{array}{l}\text { Bending the arm } \\
\text { in elbow joints } \\
\text { (the control group) }\end{array}$ & $22.7 \pm 4.7$ & $25.9 \pm 3.2$ & 5 & Reduced \\
\hline $\begin{array}{l}\text { The supination of fo- } \\
\text { rearm (the main group) }\end{array}$ & $21.7 \pm 3.8$ & $26.3 \pm 4.9$ & 4 & Reduced \\
\hline $\begin{array}{c}\text { The supination } \\
\text { of forearm } \\
\text { (the control group) }\end{array}$ & $30.5 \pm 1.3$ & $41.8 \pm 2.4$ & 5 & Reduced \\
\hline $\begin{array}{l}\text { The pronation of fo- } \\
\text { rearm (the main group) }\end{array}$ & $19.8 \pm 5.1$ & $19.8 \pm 4.6$ & 4 & Reduced \\
\hline $\begin{array}{c}\text { The pronation } \\
\text { of forearm } \\
\text { (the control group) }\end{array}$ & $30.6 \pm 6.9$ & $27.4 \pm 2.8$ & 4 & Reduced \\
\hline $\begin{array}{l}\text { Flexion and extension } \\
\text { in the wrist } \\
\text { (the main group) }\end{array}$ & $37.3 \pm 1.6$ & $24.3 \pm 5.2$ & 4 & Reduced \\
\hline $\begin{array}{l}\text { Flexion and extension } \\
\text { in the wrist } \\
\text { (the control group) }\end{array}$ & $29.7 \pm 4.3$ & $13.4 \pm 7.1$ & 4 & Reduced \\
\hline $\begin{array}{l}\text { Bending in hip joints } \\
\text { (the main group) }\end{array}$ & $43.9 \pm 1.8$ & $49.0 \pm 6.8$ & 6 & Reduced \\
\hline $\begin{array}{l}\text { Bending in hip joints } \\
\text { (the control group) }\end{array}$ & $44.2 \pm 6.3$ & $40.3 \pm 1.0$ & 6 & Reduced \\
\hline $\begin{array}{l}\text { The extension in hip } \\
\text { joints (the main group) }\end{array}$ & $37.1 \pm 7.0$ & $29.2 \pm 1.6$ & 4 & Reduced \\
\hline $\begin{array}{l}\text { The extension in hip } \\
\text { joints (the control } \\
\text { group) }\end{array}$ & $38.7 \pm 4.7$ & $38.9 \pm 4.4$ & 5 & Reduced \\
\hline $\begin{array}{l}\text { The assignment in hip } \\
\text { joints (the main group) }\end{array}$ & $36.9 \pm 5.1$ & $38.2 \pm 2.1$ & 5 & Reduced \\
\hline
\end{tabular}

(C) Kharchenko Yevhen, Vashchenko Iryna DOI (article): https://doi.org/10.32626/2227-6246.2021-53.284-305 
DOI: https://doi.org/10.32626/2227-6246.2021-53

2021. ВИПУСК 53

\begin{tabular}{|c|c|c|c|c|}
\hline $\begin{array}{c}\text { Motor acts being } \\
\text { tested }\end{array}$ & $\begin{array}{c}\text { The } \\
\text { amount of } \\
\text { active... }\end{array}$ & $\begin{array}{c}\text { The } \\
\text { amount of } \\
\text { passive... }\end{array}$ & $\begin{array}{c}\text { Muscle } \\
\text { strength } \\
\ldots\end{array}$ & $\begin{array}{c}\text { A } \\
\text { muscle } \\
\text { tone }\end{array}$ \\
\hline $\begin{array}{c}\text { The assignment in } \\
\text { hip joints (the control } \\
\text { group) }\end{array}$ & $39.0 \pm 2.8$ & $39.4 \pm 4.7$ & 6 & Reduced \\
\hline $\begin{array}{c}\text { Bringing in hip joints } \\
\text { (the main group) }\end{array}$ & $33.6 \pm 4.2$ & $29.4 \pm 1.1$ & 5 & Reduced \\
\hline $\begin{array}{c}\text { Bringing in hip joints } \\
\text { (the control group) }\end{array}$ & $37.3 \pm 1.4$ & $30.7 \pm 2.5$ & 6 & Reduced \\
\hline $\begin{array}{c}\text { The external rotation } \\
\text { in the hip joint } \\
\text { (the main group) }\end{array}$ & $30.8 \pm 2.4$ & $33.8 \pm 5.9$ & 5 & Reduced \\
\hline $\begin{array}{c}\text { The external rotation } \\
\text { in the hip joint } \\
\text { (the control group) }\end{array}$ & $29.4 \pm 8.1$ & $38.6 \pm 7.0$ & 5 & Reduced \\
\hline $\begin{array}{c}\text { The internal rotation } \\
\text { in the hip joint } \\
\text { (the main group) }\end{array}$ & $43.7 \pm 7.2$ & $32.7 \pm 8.1$ & 5 & Reduced \\
\hline $\begin{array}{c}\text { The internal rotation } \\
\text { in the hip joint } \\
\text { (the control group) }\end{array}$ & $40.1 \pm 8.2$ & $31.8 \pm 3.1$ & 6 & Reduced \\
\hline $\begin{array}{c}\text { Bending in knee joints } \\
\text { (the main group) }\end{array}$ & $59.3 \pm 5.0$ & $78.1 \pm 6.6$ & 7 & Reduced \\
\hline $\begin{array}{c}\text { Bending in knee joints } \\
\text { (the control group) }\end{array}$ & $67.1 \pm 3.2$ & $62.4 \pm 5.5$ & 7 & Reduced \\
\hline $\begin{array}{c}\text { Bending in ankle joints } \\
\text { (the main group) }\end{array}$ & $38.0 \pm 4.1$ & $38.7 \pm 4.2$ & 5 & Reduced \\
\hline $\begin{array}{c}\text { Bending in ankle joints } \\
\text { (the control group) }\end{array}$ & $38.4 \pm 8.1$ & $35.2 \pm 0.1$ & 5 & Reduced \\
\hline $\begin{array}{c}\text { The extension in ankle } \\
\text { joints (the main group) }\end{array}$ & $44.1 \pm 7.9$ & $45.8 \pm 7.3$ & 6 & Reduced \\
\hline $\begin{array}{c}\text { The extension in ankle } \\
\text { joints (the control } \\
\text { group) }\end{array}$ & $48.9 \pm 1.3$ & $47.9 \pm 4.4$ & 6 & Reduced \\
\hline
\end{tabular}




\section{Conclusions}

The psychological principles of the development of general compensatory reactions of the patient in a case of physical rehabilitation of patients with ischemic stroke were proposed in this research. These principles are: 1) the principle of actualization of the defect; 2 ) the principle of progressive mobilization of compensatory mechanisms of psychomotor activity; 3 ) the principle of continuous reverse of concentration of compensatory mechanisms of the psyche of the person; 4) the principle of sanctioning compensatory mechanisms of the psyche of the person; 5) the principle of relative stability of the compensatory mechanisms of the psyche of the patient.

In a case of ischemic strokes there is a certain dynamics of recovery of locus disorders. Firstly, reflex functions and tone are restored, then psychomotor actions (global and coordinating synkinesis) and auxiliary actions appear, and finally arbitrary movements are restored. In order to begin to restore tendon reflexes and muscle tone, it is necessary to normalize the functions of the spinal cord.

Compensation of certain function that had disorders is based on the restructuring of the old stereotype and the development of a new dynamic stereotype. The most important point of compensation for structural and functional disorders in the case of psychomotor pathology is active participation in the rehabilitation process and the patient himself/herself, who should seek to activate the body's systems, which are not affected at all or suffered insignificantly. It has been shown that due to new unaffected parts of the central nervous system, it is possible to rearrange the innervation between the antagonists.

\section{Literature}

Онуфрієва Л., Івашкевич Е. The development of learner's autonomy by the way of the formation of social intelligence. Збірник наукових праць «Проблеми сучасної психологї̈, 2021, 51, 9-32. URL : https://doi.org/10.32626/2227-6246.2021-51.9-32.

(C) Kharchenko Yevhen, Vashchenko Iryna DOI (article): https://doi.org/10.32626/2227-6246.2021-53.284-305 
DOI: https://doi.org/10.32626/2227-6246.2021-53

2021. випуск 53

Харченко Є., Куриця Д. Psychological ways of providing primary medical sanitary help for people who use psychoactive substances. Збірник наукових праць «Проблели сучасної психологї̈, 2021, 51, 215240. URL : https://doi.org/10.32626/2227-6246.2021-51.215-240.

Hardeman, Rachel R., Medina, Eduardo M., \& Kozhimannil, Katy B. Structural Racism and Supporting Black Lives - The Role of Health Professionals. New England Journal of Medicine, 2016, 375 (22), 2113-2115. DOI 10.1056/NEJMp1609535.

Hayden, F.G., Farrar, J., \& Peiris, J.S. Towards improving clinical management of Middle East respiratory syndrome coronavirus infection. Lancet Infect Dis., 2014, 14 (7), 544-546. DOI 10.1016/S14733099(14)70793-5.

Khwaja, A. KDIGO clinical practice guidelines for acute kidney injury. Nephron Clin Pract., 2012, 120, 179-84.

Mykhalchuk, N., Pelekh, Yu., Kharchenko, Ye., Ivashkevych, Ed., Ivashkevych, Er., Prymachok, L., Hupavtseva, N., \& Zukow, W. The empirical research of the professional reliability of 550 doctors during the COVID-19 pandemic in Ukraine (March-June, 2020). Balneo Research Journal, 2020, 368, 11 (3), 393-404. URL : http://dx.doi. org/10.12680/balne.

Onufriieva, L., Chaikovska, O., Kobets, O., Pavelkiv, R., \& Melnychuk, T. Social Intelligence as a Factor of Volunteer Activities by Future Medical Workers. Journal of History Culture and Art Research, 2020, 9 (1), 84-95. URL : http://dx.doi.org/10.7596/taksad.v9i1.2536.

Villar, J., Blanco, J., \& del Campo, R. Spanish Initiative for Epidemiology, Stratification \& Therapies for ARDS (SIESTA) Network. Assessment of $\mathrm{PaO} / \mathrm{FiO}$ for stratification of patients with moderate and severe acute respiratory distress syndrome. BMJ Open, 2015, 5 (3). URL : http://10.1136/bmjopen-2014-006812.

\section{References}

Onufriieva, L., \& Ivashkevych, Ed. (2021). The development of learner's autonomy by the way of the formation of social intelligence. Zbirnyk naukovykh prats "Problemy suchasnoi psykholohii» - Collection of research papers "Problems of Modern Psychology», 51, 9-32. Retrieved from https://doi.org/10.32626/2227-6246.2021-51.9-32.

Kharchenko, Ye., \& Kurytsia, D. (2021). Psychological ways of providing primary medical sanitary help for people who use psychoactive substances. Zbirnyk naukovykh prats «Problemy suchasnoi psykholohii» - Collection of research papers "Problems of modern psycholo-

(C) Kharchenko Yevhen, Vashchenko Iryna

DOI (article): https://doi.org/10.32626/2227-6246.2021-53.284-305 
DOI: https://doi.org/10.32626/2227-6246.2021-53 2021. ВИПУСК 53

gy», 51, 215-240. Retrieved from https://doi.org/10.32626/22276246.2021-51.215-240

Hardeman, Rachel R., Medina, Eduardo M., \& Kozhimannil, Katy B. (2016). Structural Racism and Supporting Black Lives - The Role of Health Professionals. New England Journal of Medicine, 375 (22), 2113-2115. Retrieved from http://10.1056/NEJMp1609535.

Hayden, F.G., Farrar, J., \& Peiris, J.S. (2014). Towards improving clinical management of Middle East respiratory syndrome coronavirus infection. Lancet Infect Dis., 14 (7), 544-546. Retrieved from http://10.1016/S1473-3099(14)70793-5.

Khwaja, A. (2012). KDIGO clinical practice guidelines for acute kidney injury. Nephron Clin Pract., 120, 179-84.

Mykhalchuk, N., Pelekh, Yu., Kharchenko, Ye., Ivashkevych, Ed., Ivashkevych, Er., Prymachok, L., Hupavtseva, N., \& Zukow, W. (2020). The empirical research of the professional reliability of 550 doctors during the COVID-19 pandemic in Ukraine (March-June, 2020). Balneo Research Journal, 368, 11 (3), 393-404. Retrieved from http:// dx.doi.org/10.12680/balne.

Onufriieva, L., Chaikovska, O., Kobets, O., Pavelkiv, R., \& Melnychuk, T. (2020). Social Intelligence as a Factor of Volunteer Activities by Future Medical Workers. Journal of History Culture and Art Research, 9 (1), 84-95. Retrieved from http://dx.doi.org/10.7596/taksad. v9i1.2536.

Villar, J., Blanco, J., \& del Campo, R. (2015). Spanish Initiative for Epidemiology, Stratification \& Therapies for ARDS (SIESTA) Network. Assessment of $\mathrm{PaO} / \mathrm{FiO}$ for stratification of patients with moderate and severe acute respiratory distress syndrome. BMJ Open, 5 (3). Retrieved from https://doi.org/10.1136/bmjopen-2014-006812.

\section{Харченко Євген, Ващенко Ірина. Особливості корекції психомоторних розладів хворих на ішемічний інсульт: психологічний аспект}

\section{АНОТАЦІЯ}

Завдання статmі - запропонувати авторське розв'язання проблеми визначення біомеханічних законів, що відображають картину розладів психомоторної функції; провести дослідження та проаналізувати отримані дані щодо початкового стану рухової функції пацієнтів з ішемічним інсультом підгрупи «плезія + парез»; запропонувати психологічні принципи розвитку загальних компенсаторних реакцій пацієнта у разі фрізичної реабілітації хворих на ішемічний інсульт.

(C) Kharchenko Yevhen, Vashchenko Iryna DOI (article): https://doi.org/10.32626/2227-6246.2021-53.284-305 
DOI: https://doi.org/10.32626/2227-6246.2021-53

2021. випуск 53

Методи дослідження. Використано метод аналізу літературних джерел; метод педагогічного спостереження; психолого-педагогічний експеримент; метод дослідження психоемоційного стану (тест М. Люшера).

Результати дослідження. Доведено, що картина розладів психомоторної функції підпорядковується певним біомеханічних законам: 1. Правило перерозподілу функцій ураженої кінцівки. Функціональні можливості ураженої кінцівки підтримувати вагу тіла значно знижуються. Це особливо помітно в період одиночної опори: зменшуються як абсолютні, так і відносні за часовими інтервалами функції одиночної опори, а також тривалість періоду опори. Але таке розвантаження хворого боку повинно бути компенсовано, адже період опори здорової ноги суттєво збільшується. Зміна періодів опори має очевидний наслідок - збільшення на хворому боці часу перенесення, на здоровому - його скорочення. 2. Правило фрункціонального копіювання рухів іншої особи. Патологічна асиметрія не вигідна організму ні з точки зору енергетики, ні з точки зору механіки. Необхідність підтримувати відносну симетричність функцій правого $i$ лівого боків тіла призводить до такого висновку: здорова сторона тіла (або кінцівка) має неабиякий функціональний резерв, на відміну від хворої, тому зменшення функціональної асиметрії відбувається шляхом наближення зразка функціонування здорової кінцівки до зразка хворої. З. Правило забезпечення оптимуму в психомоторній діяльності. Функціонування всіх елементів нормального циклу психомоторної діяльності $\epsilon$ основою фізіологічної оптимальності індивіда. Будь-які відхилення від фізіологічної оптимальності вимагають включення додаткових адаптивних резервів, які на ураженому боці дещо змінені. Забезпечити хворому оптимальність функціонування можна за рахунок функціонального напруження здорового боку.

Висновки. Запропоновано психологічні принципи формування загальних компенсаторних реакцій пацієнта у випадку проведення фізичної реабілітації хворих з ішемічним інсультом, а саме: 1) принцип актуалізації дефекту; 2) принцип прогресивної мобілізації компенсаторних механізмів психомоторної діяльності; 3) принцип безперервного зворотного концентрування компенсаторних механізмів психіки особистості; 4) принцип санкціонування компенсаторних механізмів психіки особистості; 5) принцип відносної стійкості компенсаторних механізмів психіки особucmocmi.

(C) Kharchenko Yevhen, Vashchenko Iryna

DOI (article): https://doi.org/10.32626/2227-6246.2021-53.284-305 http://journals.uran.ua/index.php/2227-6246 
DOI: https://doi.org/10.32626/2227-6246.2021-53

2021. ВИПУСК 53

Доведено, що у випадку ішемічних інсультів виявляється певна динаміка відновлення локусних розладів. Спочатку відновлюються рефлекторні функції й тонус, а потім з'являються психомоторні дії (глобальні та координаторні сінкінезії), а також допоміжні дії, i, нарешті, відновлюються довільні рухи. Для того, щоб почали відновлюватися сухожильні рефрлекси і м'язовий тонус, необхідна нормалізація функкій спинного мозку.

Наголомено, що компенсація певних функцій, що мали розлади, заснована на перебудові старого стереотипу і виробленні нового динамічного стереотипу. Важливим моментом компенсації структурно-функціональних розладів у випадку патології психомоторики є активна участь у процесі реабілітації й самого хворого, який має прагнути активізувати системи організму, що зовсім не постраждали або постраждали несуттєво. Було показано, що за рахунок нових - тих, що не постраждали відділів центральної нервової системи можливою постає перебудова іннервації між антагоністами.

Ключові слова: психомоторні розлади хворих, ішемічний інсульт, принцип актуалізації дефекту, принцип прогресивної мобілізації компенсаторних механізмів психомоторної діяльності, принцип безперервного зворотного концентрування компенсаторних механізмів психіки особисmocmi.

Харченко Евгений, Ващенко Ирина. Особенности коррекции психомоторных расстройств больных с ишемическим инсультом: психологический аспект

\section{АННОТАЦИЯ}

Задачи статьи - предложить авторское решение проблемы определения биомеханических законов, отражающих картину расстройств психомоторной функции; провести исследование и проанализировать полученные данные относительно исходного состояния двигательной функции пациентов с ишемическим инсультом подгруппы «плезия + парез»; предложить психологические принципы развития общих компенсаторных реакций пациента в случае физической реабилитации больных с ишемическим инсультом.

Методы исследования. Использованы метод анализа литературных источников; метод педагогического наблюдения; психолого-педа-

(c) Kharchenko Yevhen, Vashchenko Iryna DOI (article): https://doi.org/10.32626/2227-6246.2021-53.284-305 
гогический эксперимент; метод исследования психоэмоционального состояния (тест М. Люшера).

Результаты исследования. Доказано, что картина расстройств психомоторной функции подчиняется определенным биомеханическим законам: 1. Правило перераспределения функций пораженной конечности. Функциональные возможности пораженной конечности поддерживать вес тела значительно снижаются. Это особенно заметно в период одиночной опоры: уменьшаются как абсолютные, так и относительные по временным интервалам функции одиночной опоры, а также продолжительность периода опоры. Показано, что такого рода нагрузки больной стороны должны быть компенсированы, ведь период опоры здоровой ноги существенно увеличивается. Изменение периодов опоры имеет очевидное последствие - увеличение на больной стороне времени переноса, на здоровой - его сокращение. 2. Правило функционального копирования движений другого лица. Патологическая асимметрия не выгодна организму ни с точки зрения энергетики, ни с точки зрения механики. Необходимость поддерживать относительную симметричность функций правой и левой сторон тела приводит к следующему выводу: здоровая сторона тела (или конечность) имеет больщий функциональный резерв, чем больная, поэтому уменьшение функциональной асимметрии происходит путем приближения образца функционирования здоровой конечности к образцу больной. 3. Правило обеспечения оптимума в психомоторной деятельности. Функционирование всех элементов нормального цикла психомоторной деятельности является основой физиологической оптимальности индивида. Любые отклонения от физиологической оптимальности требуют включения дополнительных адаптивных резервов, которые на пораженной стороне несколько изменены. Обеспечить больному оптимальность функционирования можно за счет функционального напряжения здоровой стороны тела.

Выводы. Предложены психологические принципы формирования общих компенсаторных реакций пациента в случае проведения физической реабилитации больных с ишемическим инсультом, а именно: 1) принцип актуализации дефекта; 2) принцип прогрессивной мобилизации компенсаторных механизмов психомоторной деятельности; 3) принцип непрерывного обратного концентрирования компенсаторных механизмов психики личности; 4) принцип санкционирования компенсаторных механизмов психики личности; 5) принцип относительной устойчивости компенсаторных механизмов психики личности.

(C) Kharchenko Yevhen, Vashchenko Iryna

DOI (article): https://doi.org/10.32626/2227-6246.2021-53.284-305 
DOI: https://doi.org/10.32626/2227-6246.2021-53

2021. ВИПУСК 53

Доказано, что в случае ишемических инсультов организмом приобретается определенная динамика восстановления локусных расстройств. Сначала восстанавливаются рефлекторные функции и тонус, а затем появляются психомоторные действия (глобальная и координаторная синкинезия), а также восстанавливаются вспомогательные действия, и, наконеи, произвольные движения. Для того, чтобы начали восстанавливаться сухожильные рефлексы и мышечный тонус, необходима нормализация функций спинного мозга.

Отмечено, что компенсация определенных функций, которые имели расстройства, основана на перестройке старого стереотипа и выработке нового динамического стереотипа. Важным моментом компенсации структурно-функциональных расстройств в случае патологии психомоторики является активное участие в процессе реабилитации и самого больного, который должен стремиться активизировать системы организма, которые совсем не пострадали или пострадали незначительно. Было показано, что за счет новых - непострадавших - отделов центральной нервной системы возможна и перестройка иннервации между антагонистами.

Ключевые слова: психомоторные расстройства больных, ишемический инсульт, принцип актуализации дефекта, принцип прогрессивной мобилизации компенсаторных механизмов психомоторной деятельности, принцип непрерывного обратного концентрирования компенсаторных механизмов психики личности.

Original manuscript received March 31, 2021 Revised manuscript accepted May 12, 2021 